\title{
Scenario of Chilli Production and Hindrances Faced by the Growers of Sindh Province of Pakistan
}

ISSN: 2637-7659

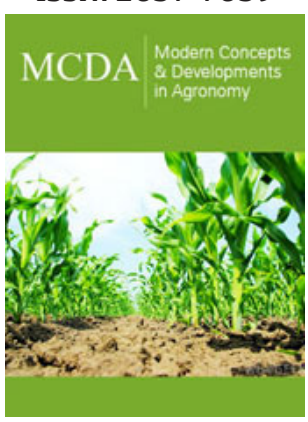

*Corresponding author: Saima Arain, Plant Breeding and Genetics Division, Tando Jam, Sindh, Pakistan

Submission: 侮 May 23, 2019

Published: 海 May 31, 2019

Volume 4 - Issue 2

How to cite this article: Saima A. Scenario of Chilli Production and Hindrances Faced by the Growers of Sindh Province of Pakistan. Mod Concep Dev Agrono.4(3). MCDA.000588.2019.

DOI: 10.31031/MCDA.2019.04.000588

Copyright@ Saima Arain, This article is distributed under the terms of the Creative Commons Attribution 4.0 International License, which permits unrestricted use and redistribution provided that the original author and source are credited.

\author{
Saima Arain* \\ Plant Breeding and Genetics Division, Pakistan
}

\begin{abstract}
Chilli (Capsicum annum L.) is an economically important crop in Pakistan and globally. Chilli native to America, were brought to sub-continent by the Portuguese traders from Brazil. In Pakistan, Sind province is the major producer of chilli crop followed by the Punjab and Baluchistan. It is not only used as food but also as main flavouring spice in the country cuisine. Pakistan was the 5th largest exporter but facing continues decline in its production due to various problems. Pests (whitefly, aphids, thrips, mites and heliothis) and pathogens (dieback, damping-off, CMV, powdery and downy mildews) are the main culprits in declining the national chilli production. Higher Aflatoxin level (40-300ppm) is one of the serious reasons behind declining export. In view of the mentioned problems we need strict strategy to overcome all these issues in order to increase our yield, export and economy.
\end{abstract}

\section{Introduction}

Chilli (Capsicum annum/Capsicum frutescens L.) is widely cultivated and cash crops around the world, used both as spice and as medicinal plant. Chilli also called red pepper belongs to the genus capsicum, under the solanaceae family, similar botanically to potatoes, tomatoes and egg plants. The genus capsicum is diploid with $\mathrm{x}=12$ basic chromosomes and $2 n+2 x=24$ (Pickersgill, 1977), whereas wild type species carry $2 n=26$. The word Capsicum derived from greek word kapto meaning "to bite" or "to swallow". Chillies are native to Mexico, assumed to have originated from South America, from their introduced to central America [13]. Chillies were introduced to sub-continent (Indo-Pak) by Portuguese traders from Brazil. Chillies are referred to as chillies, bell peppers, Chile, paprika, hot peppers, red peppers, pod peppers, pimento, cayenne peppers, and capsicum in various regions of the world. However, in general the chillies are the smaller-sized and more pungent types, whereas, the quite larger, mildly to moderately pungent types are capsicums. Its categorization is difficult due to vast number of varieties available and the continuous creation of new varieties through the use of hybridization. Chillies have been used widely for its unique pungent taste and dazzling colours. Many varieties of chillies are present, among these commonly used are Capsicum annum (sweet or bell pepper) and capsicum frutescens (hot pepper). The optimum day temperatures for chilli pepper growth range from 20 to $30{ }^{\circ} \mathrm{C}$ [4]. Chilli is often crosspollinated crop with an extent of over $63 \%$. Chillies are valued principally for their high pungency and bright red colour. The pungency in chilli pepper is due to the substance called Capsaicin $\left(\mathrm{C}_{18} \mathrm{H}_{27} \mathrm{NO}_{3}\right)$ (N-vanillyl-8-methyl-6-(E)-noneamide) and several other chemicals, collectively known as capsaicinoids, the higher the capsaicin the hotter the chilli. This substance produces the heat sensation; stimulate the human body to trigger heat receptors viz., Transient Receptor Potential Vanilloid 1 (TRPV1). This fiery reaction can be overcome by taking the Milk that contains a protein named casein, which grasps the oily capsaicin to carry them away. Moruga Scorpion is considered the hottest chilli in the world with more than 1.2-2 million SHUs, reported by Mexican university in 2012. The Capsaicin is basically produced in the seed-bearing membranes of the fruit. Wilbur Scoville in 1912 introduced a scale known as Scoville heat scale used to measure the hotness of the chillis, composed of heat units ranging from 0-16 million, depending on the capsaicin content of the chillis. Chilli has various chemical contents viz., vitamins, minerals, carotenoids, proteins and fibre, making beneficial for humans indifferent ways. Red colour in chillies is due to the presence of pigment capsanthin (primary carotenoid). Other bioactive compounds found in chilli are Lutein known to improve eye health is abundantly found in green chillies. Whereas yellow chillies contain a 
carotenoid viz., Volaxanthin, sinapic acid an antioxidant helpful in neuroprotection, and Ferulic acid compound helps in heart disease, cancer and even diabetes. Chilli crop faces invasion of more than over 293 species of insects and mites in the field and storage [5].

\section{Status of Pakistan in the world chilli market}

Pakistan is going through difficult period to compete global market for chilli export. Major hindrances are higher price compared to other exporting countries, secondly its lower quality. Chilli export of the Country can be strengthened by strictly following the quality improvement laws. Although, Pakistan is among the major chilli producers and exporters viz. China, Morocco, Mexico and Turkey, but in the global scenario 25\% (11lac tons) of the total chilli produce is contributed by India. The global chilli production is about 7 million tons from an area of 1.5 million hectares. Pakistan accounts for 2 lac tons, less than China (4lac) and Mexico (3tons). Among the top chilli producers and exporters India supplies 25\%, China 24\%, Spain 17\%, Mexico 8\%, Pakistan 7.2\%, Morocco $7 \%$ and Turkey $4.5 \%$. India not only leading in production but also in export, supplying one fourth of total chillies exported globally. In Pakistan chilli is economically important and valuable cash crop, grown in all four provinces and widely used in Pakistani cuisine like other South Asian countries. Chillies are used in a variety of ways in making the ordinary dishes spicy, delicious and more captivating in traditional cuisine of Pakistan, also used as vegetable in pickles, salads, and in appetizers. Pungency in chillies makes them useful in medicine preparation [6]. Chillies are used in all arthritis treatments, also in neuropathic pain and dermatologic conditions. Pakistan is the fourth largest producer of red chillies after India, China and Mexico. The total production of red chilli in Pakistan was recorded143.1 thousand tonnes, from an area of 64.2 thousand ha [7]. In Sindh, Chillies are cultivated on an area of 38.4 thousand hectares with production of 53.7 thousand tonnes. The average yield of 1.7 tons per hectare contributes 1.5 percent of the country's GDP. In Pakistan, Kunri a small town of Umer Kot district, formerly known as chilli capitol of Asia. It contributes about $85 \%$ of Pakistan's Red Chilli production and is known as one of the largest production centres.

\section{Famous chilli varieties cultivated in sindh}

Important varieties grown in the country are Longi (Dundi cut), Talhari, Gothki, Tatapuri, Narwala, Qaisar, area under total cultivation in Sindh is about $50 \%$ of total acreage under chilies in Pakistan. Some of the famous varieties planted in Sindh province namely, Sanam, Ghotki, Longi, Talhari, Kunri-1. However, three famous Chilli varieties viz., Maxi, Desi \& Nageena mostly grown in Kunri are known as "Kunri chilli bunch".

\section{Planting season of chilli}

The chilli plantation is recommended from $15^{\text {th }}$ March onward, but growers from southern Mirpurkhas try to plant the crop in February. The kunri in Umer Kot district stoods first to take the crop to the markets in early august, that form Tando Allahyar (formerly part of Hyderabad) comes to the market in mid of August.
It thrives well in warm, humid weather and clean, dry conditions for maturity. It is semi-perennials (if planted under favourable conditions, it will behave like perennial, but in less ideal conditions, it will act like an annual, generally these are the plants can't survive cold winter) in nature and also planted as annual crop. Optimum daytime mean temperature for better chilli growth is $20-25^{\circ} \mathrm{C}$ and nights below $20^{\circ} \mathrm{C}$.

\section{Soil requirements}

Chilli crop can thrive well under warm weather in a sandy loam type soil with a pH range of 5.5 to 8.5. Ploughing twice with mould board plough is recommended prior to transplantation. This crop is very sensitive to water logging and can tolerate water stress better than standing water which results into many soil born diseases. Likewise, growth of root knot nematodes indicates very poor soil conditions. Draining system can be improved by applying the organic matters and also by planting the deep-rooted crops in the field prior to chilli cultivation.

\section{Weeding and earthling up}

Weeds should be removed regularly on monthly basis, or as required. Weeds cause great losses to crop yield by competing for water, nutrients and light. Due to their fast growth and vigour they soon surpass the crop and utilize more food as compared with the actual crop, thus cause great yield losses. Earthling up at flowering stage helps plant growth and development and also provides improvement against lodging.

\section{Use of farmyard manure and fertilizers}

For soil preparation one month ahead of bed making, welldecomposed farmyard manure should be incorporated at the rate of $25-35 t / h^{-1}$ one month before seed bed preparation. Prior to transplantation of phosphorus, nitrogen and potash should be thoroughly blended in the soil at the rate of $70-80 \mathrm{~kg}, 35 \mathrm{~kg}$ of and $50 \mathrm{~kg}$ of per hectare, respectively. At the time of fruit setting $25 \mathrm{~kg}$ per hectare of nitrogen may be applied as supplementary dose. Large application of nitrogenous fertilizers should be avoided as it increases vegetative growth and delays maturity, chilli love potassium.

\section{Irrigation requirements of chilli}

Chilli crop should be irrigated immediately after sowing and transplantation followed by weekly irrigation in the summer. For better establishment of the seedlings it is necessary at least 2 to 3 irrigations should be applied within first two weeks after transplantation. After that irrigations should be applied on ten to fifteen days intervals and should be altered according to the climatic conditions. Irrigation is especially very important at the time of flowering and fruit development.

\section{Weed management}

Effective weed control is very important for chilli growers. As weeds can be host to various virus or insect pests. To control the weeds use of suitable herbicides, manual weeding and tillage should be practiced. 


\section{Fruit harvesting and drying}

Crop harvest should be started when fruits reach to fully ripened stage with red colour. Fruits should be harvested promptly after it become fully developed and mature; it will promote fresh flowering and more harvests. For drying purpose, fruits should be spread in thin layers on recommended mats under the sun to avoid any infestation or rotting. At night fruit should be covered to protect from any moisture due to dew. Fruit moisture should be $70-75 \%$ at the time of harvesting and become $8-10 \%$ after drying.

\section{Major insects faced by chilli crop}

Various pests attack and damage the chilli crop through the crop season viz., white fly, aphids, leaf hoppers, jassids, heliothis, thrips, mite cut worms, ear wigs, crickets, root grubs, pod borers, flea Beat etc.

\section{Whitefly}

Whitefly (aleyrodidae) is soft bodied insect with wings similar to aphids (Figure 1). They inhabit

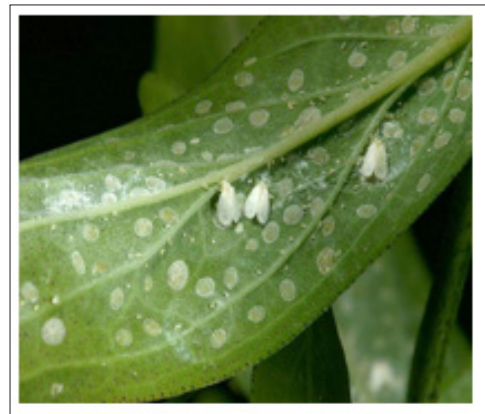

Figure 1: Whitefly.

underneath the leaves in groups. They feed on warm weather vegetables and produce a sticky substance known as honeydew, which can trigger fungal disease. Plants become weak, wilted and stunted in growth due to inability to accomplish the process of photosynthesis after white fly feed on the plants. To differentiate between white flies and aphids just shake the plant, whiteflies fly off, whereas aphids stay sticking.

\section{Aphids (green plant lice)}

Aphids also known as green plant lice are serious wingless pests with pear shape, can attack chilli crop from $2^{\text {nd }}$ and $5^{\text {th }}$ week after transplantation (Figure 2). Adults can produce 8 to 22 nymphs in 2 to 3 weeks. They are tiny $(1-10 \mathrm{~mm})$ sap sucking insects with green and black body, therefore according to the colours known as greenfly or black fly. They produce fully functional pregnant young ones; in warm weather they take only about 7 days to become fully mature ready to give birth. Hey can give birth to 3-10 young ones per day for about 4 weeks. Their growth should be controlled in the early stage, any delay can result into thousands and hundreds of thousands, as they are mostly born wingless, hence spread by walking. Aphids weaken the plant by sucking he sap (sugary solution) known as "honeydew ". The sticky, thick honeydew solution covers the leaf and collects dust, moreover, this sugary solution stimulates sooty mould growth, in turn leaves become black. Natural ways to control the aphid infestation is by attracting natural predators like lady birds, crab spider and hoverfly.

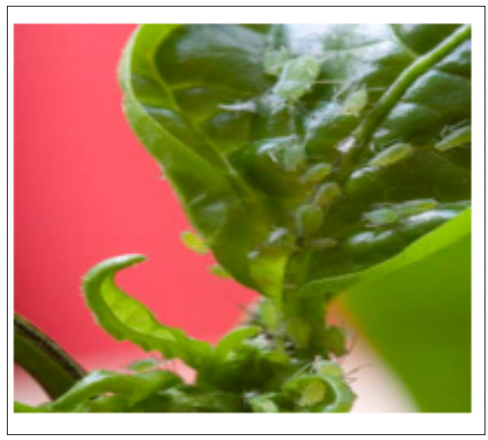

Figure 2: Aphids (green plant lice).

\section{Thrips}

Thrips are minute insects, individually so small in size that they can pass unnoticed, but breath taking when in clusters (Figure 3). Out of 5000 thrips species; only few 100s invade cultivated crops. Especially, Scirtothrips dorsalis Hood attacks chilli crop to greater level. Besides Pakistan thrips has also been reported from Japan, Australia, Thailand, SriLanka, West Malaya New Guinea, Java and Solomon Island. Thrips penetrate in the chilli plant tissues by using piercing mouth parts. Adults and nymphs especially infest soft leaves and feed on sap. Thrips attack depicts a typical leaf curl virus developing into a boat like shape. However, under acute infestation, leaves become brittle, stunted plant growth, malformed tender shoots, buds and blossoms

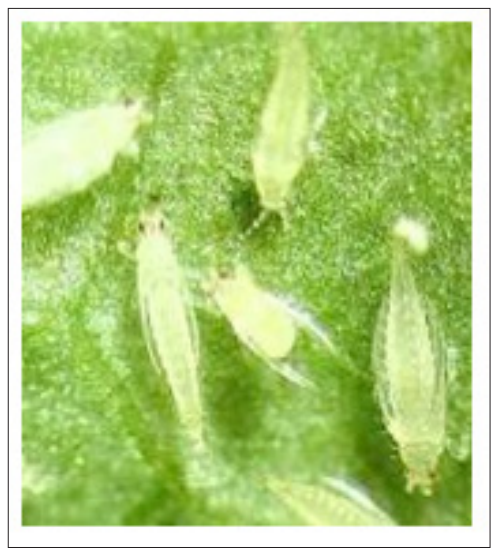

Figure 3: Thrips.

\section{Helicoverpa armigera (Heliothis)}

Chilli fruit borer Helicoverpa armigera previously known as Heliothis armiger is distributed worldwide including Asia (Figure 4). Besides chilli wide variety of crops host this borer viz., tomato, maize, chickpea, cotton, sorghum, beans etc are among the major hosts. The young caterpillars derive food from leaves, on third developmental stage they preferably feed on buds, flowers, and pods. Making holes in the fruits, injury caused by these borers lead to fungal and bacterial infections which cause fruit rotting. 


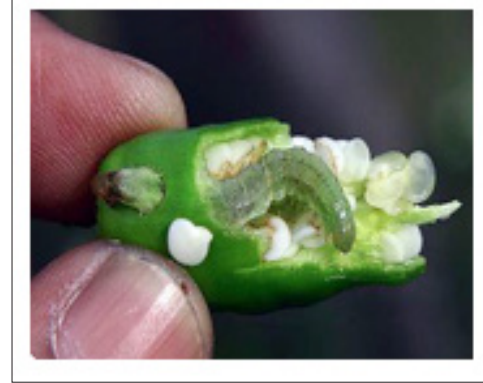

Figure 4: Helicoverpa armigera (Heliothis).

\section{Major Pests of the Chilli Crop}

\section{Damping-off}

This disease caused by Pythium aphanidermatum (Edson) is destructive to young seedlings, especially decaying the stems near the soil base (Figure 5). It causes $90 \%$ of plant death either pre or post-emergence attack both in nursery and in the field $[8,9]$. Generally damping off can be overcome by planting the treated seeds in 4-6 inches apart in well-drained beds.

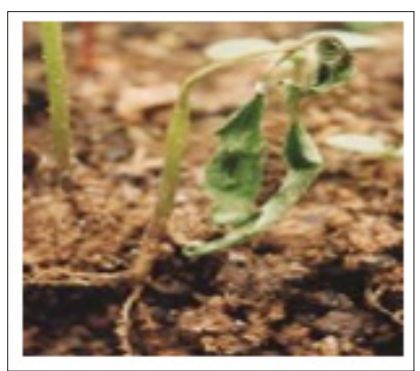

Figure 5: Damping-off: Disease caused by Pythium aphanidermatum.

\section{Cucumber Mosaic Virus}

CMV is navigated by aphid vectors, affects both yield and quality in chilli (Figure 6). Infected plants can be characterised by mosaic mottling (light to dark green or yellow patches or streaks), narrow, blistering and distorted foliage. All the infected plants should be uprooted, and application of suitable insecticide is recommended to control the aphid infestations.

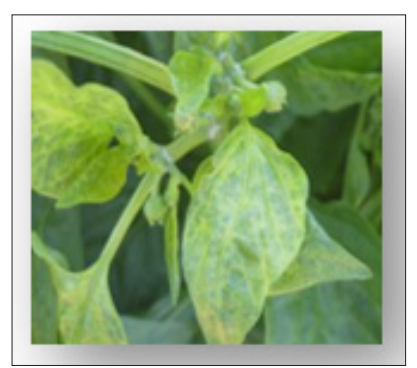

Figure 6: Cucumber Mosaic Virus.

\section{Dieback}

Chilli dieback is a fungal disease found globally on most of the vegetables crops but is serious problem for chillies (Figure 7). The disease appears at the blossoming stage of the chilli plant. To control the problem, use healthy, disease free seed. Prior to plantation seed should be treated with Trichoderma viride @10g/ $\mathrm{kg}$ (plant wise) to get rid of this problem biologically. Biocontrol agents (Trichoderma) should be saved from the chemical spray.

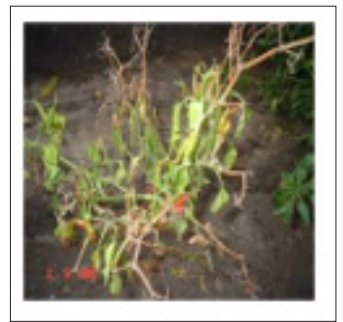

Figure 7: Chilli Leaf Curl.

\section{Chilli leaf curl}

This viral disease is caused by the whitefly, aphids, thrips and mites (Figure 8). Affected plants are characterized by the stunted growth with curling and yellowing foliage. The leaves become boat shape due to decreased size and upward curling of the leaves. All the infected plants should be removed from the field. Spray suitable insecticide to control the aphids.

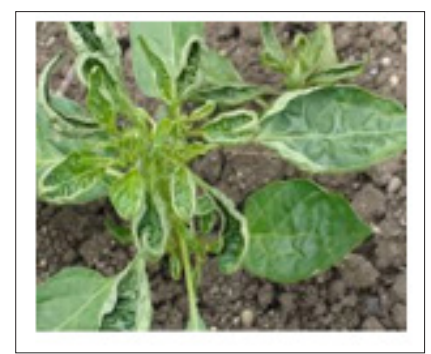

Figure 8: Whitefly.

\section{Phytophthora Blight}

The disease is distinguished by dark brown patches on stem, expanding upward from the soil line followed by an abrupt wilt of the whole plant without yellowing of leaves (Figure 9). The root and collar-rot disease is of great significance in different parts of the world including Pakistan $[10,11]$, can be controlled by planting chillies on ridges for better drainage than on furrows (Baris et al. 1986). It can be managed by crop rotation, use of resistant cultivars and application of fungicides [12]. Irrigation should be applied carefully to lessen the disease proliferation; water should be lower than the base. Additionally, avoiding cultivation of pathogen prone crops (brinjal, bean, tomato and cucurbits) may also help in controlling the disease.

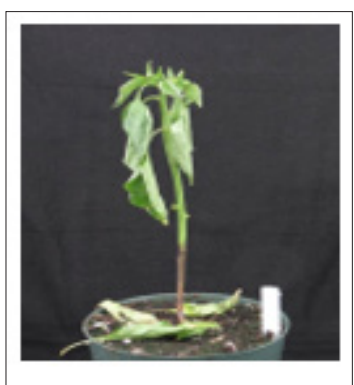

Figure 9: Phytophthora Blight. 


\section{Tobacco mosaic virus (TMV)}

To control Tobacco mosaic virus (TMV) in capsicum, smokers should wash hands before handling the crop or picking the fruits (Figure 10) [13].

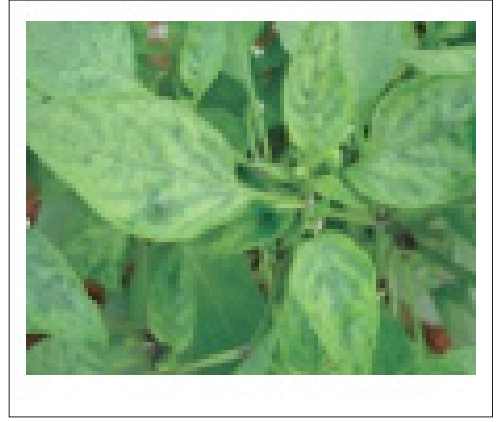

Figure 10:Tobacco mosaic virus (TMV).

\section{Powdery mildew}

Powdery mildew is the most commonly found mildew and are host specific, mildew that can infest chilli will not to other crops (Figure 11). PM growth can be characterised by the white cobweb type mycelium on the upper surface of the foliage and sometimes on other parts (stems, buds, flowers, and pods) as well. When humidity becomes very high in the summer, this fungus attacks the plant leaves, especially at the flowering and fruiting stage. The fungus only takes its nutrition from upper cells and doesn't damage the inner tissues. It can affect the crop size very badly and looks like white powdery spots on leaves as its name depicts. Optimum temperature for Powdery mildews is between $60-80^{\circ} \mathrm{F}$.

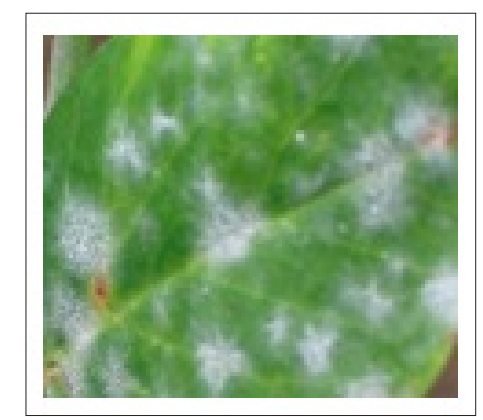

Figure 11: Powdery mildew.

\section{Downy mildew}

Downy mildew is rare but very damaging and characterized as yellow, light green or dark spots on the upper surfaces of the leaves (Figure 12). Unlike powdery mildew they are different organisms related to algae. With the disease progress foliage turn brown and dropping off. In the affected discoloured areas, a downy gray or brownish masses may appear on the underside of the foliage. Preferred temperature for downy mildews ranges between 50-75 ${ }^{\circ} \mathrm{F}$. To control this disease, resistant varieties may be preferred, affected plants may be removed and demolished. Moreover, removal of affected plant debris that may accommodate pathogens. In severe conditions drastic measures may be adopted control the spread of the disease and crop loses.

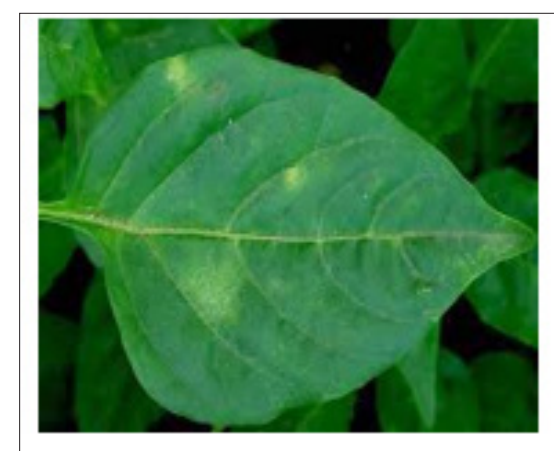

Figure 12: Downy mildew.

Other Problems Faced by the Chilli Crop

\section{EDEMA}

EDEMA is water retention disorder caused by more water uptake by the plants through rooting system then the water can be used or evaporated through leaves (Figure 13).

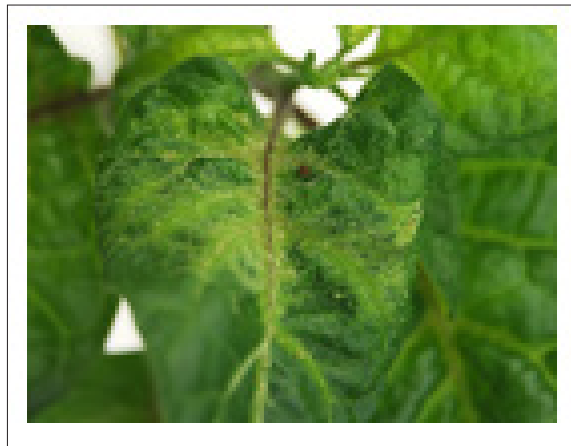

Figure 13: EDEMA.

\section{Flower drop}

Flower drop is a very common problem faced by all the chilli growers (Figure 14). The most common reason behind the flower dropping is lack of pollination due to indoor plant growth, airflow is another common cause which hinders the natural pollination. Unstable temperatures, overfeeding, application of water more than the desired amount and delayed fruit harvesting can promote flower drop. Timely fruit harvest can encourage the new flowers to develop pods, and plant could use its energy to develop new fruits instead of maintaining the older ones.

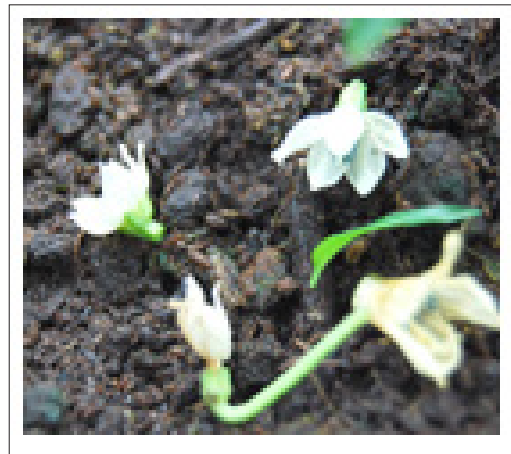

Figure 14: Flower drop. 


\section{Blossom end rot}

This is an environmental and physiological issue mainly caused by the calcium deficiency, over or sporadic watering (Figure 15). These issues can be interconnected uneven water disturbs calcium uptake and results into blossom end rot.

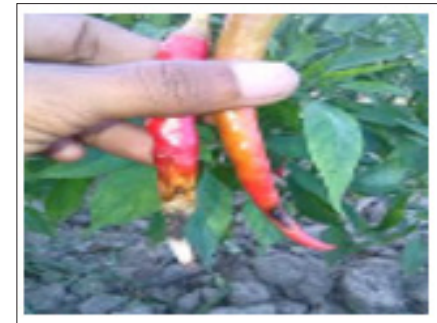

Figure 15: Blossom end rot.

\section{Aflatoxin and pesticide residues}

Toxigenic fungi (aspergillus flavus and aspergillus parasitic us) produce toxic metabolites (mycotoxins) like Aflatoxins. The most important aflatoxins found in chilli fruit are B1, B2, G1 and G2. The aflatoxins are produced during picking, drying, handling packing transportation and post-harvest storage, due to fungal activity, fruit rupturing, and damage caused by insects. The $A$. flavus contamination in Pakistan is reported 29.3\%. Consumption of contaminated products by humans can contribute to nutritional deficiencies, dysfunction of immune system and liver malignancy [14]. The twin problems faced by Pakistan in chilli export are Aflatoxin contamination and pesticide residues. Determination of aflatoxins have been done using various advance techniques viz., immunoassays [15], ELISA based Techniques [16], electrochemical sensor [17], Liquid Chromatography tandem Mass Spectrometry (LC-MS) [18], Liquid Chromatography with Fluorescence Detection (LC-FLD) [19], thin-layer chromatography [20]. Stoloff [21] reported that mismanagement of chilli from harvesting to marketing result into aflatoxin production [22-26].

\section{Conclusion}

Chili is an important cash crop of Pakistan, mainly planted for food and spices throughout the world. It is also used in herbal medicines with variety of benefits to human health. Chilli in Pakistan faces many pests, pathogens and environmental problems; which cumulatively results into reduced crop yield. Apart from diseases, other serious reasons behind the decreasing chilli production are instability of market value, expensive ad low quality inputs, poor extension services. These problems compel the farmers to prefer staple crops (e. g wheat) with good earnings, instead of taking risk of vulnerable vegetable crops. Besides production, chilli export has also been affected by the higher Aflatoxin level, which is very harmful to the human health. Pakistan should focus both on yield increases and to reduce the aflatoxin contamination. Hence, to increase our production and export, government should ensure availability of good quality inputs with reasonable price, good quality irrigation water, training of farmers and establishment of strong extension services. This support will encourage the farmers to prefer cultivation of this valuable crop and uplift their social status, also help the country to earn foreign exchange by increasing export.

\section{References}

1. Bosland PW (1996) Capsicums: Innovative uses of an ancient crop. In: Janick J (Ed.), Progress in new crops. Ash's Press Arlington, Texas, USA, pp. 479-487.

2. Perry L, Dickau R, Zarrillo S, Holst I (2007) Starch fossils and the domestication and dispersal of chili peppers (Capsicum spp. L.) in the Americas. Science 315(5814): 986-988.

3. Bridgemohan P, Mohammed M, Bridgemohan RSH (2018) Capsicums fruit and vegetable phytochemicals: chemistry and human health. $\left(2^{\text {nd }}\right.$ edn), Yahia EM (Ed.), John Wiley \& Sons Ltd., Hoboken, New Jersey, USA, Vol. 2.

4. Berke T, Black LL, Talekar NS (2005) Suggested cultural practices for chilli pepper. In: International Co-Operator's Guide.

5. Kaur G, Sangha KS (2016) Diversity of arthropod fauna associated with chilli (Capsicum annuum L.) in Punjab Gurlaz. Journal of Entomology and Zoology Studies 4(5): 390-396.

6. Escogido RML, Mondragon GEG, Tzompantzi VE (2011) Chemical and pharmacological aspects of capsaicin. Molecules 16(2): 1253-1270.

7. GOP (2017) Pakistan statistical yearbook 2017.

8. Sowmini R (1961) Studies on phycomycetes in agricultural soils with special reference to Pythiaceae. MSc (Agri) Thesis, University of Madras, India, p. 160.

9. Majeed M, Mir GH, Hassan M, Mohuiddin FA, Paswal S, et al. (2018) Damping off in chilli and its biological management-a review. Int J Curr Microbiol App Sci 7(4): 2175-2185.

10. Mehboob UR, Nawab A, Shahid K, Hussain SA (1998) Irrigation frequency and planting method reduce root rot in chilies (Capsicum annum L). Sarhad J Agric 14: 549-551.

11. Naz I, Ahmad M, Alam S, Tahirand M, Raziq F (2007) Control of root and collar rot disease, a serious threat to chilies production in neap. Sarhad J Agric 23(2): 451-454.

12. Babadoost M, Pavon C, Islam SZ, Tian D (2015) Phytophthora blight (Phytophthora capsici) of pepper and its management. Acta Horticulturae 1105: 61-66.

13. Kumar S, Udaya Shankar AC, Nayaka SC, Lund OS, Prakash HS (2011) Detection of tobacco mosaic virus and tomato mosaic virus in pepper and tomato by multiplex RT-PCR. Lett Appl Microbiol 53(3): 359-363.

14. Wagacha JM, Muthomi JW (2008) Mycotoxin problem in Africa: current status, implications to food safety and health and possible management strategies. Int J Food Microbiol 124(1): 1-12.

15. Saha D, Acharya D, Roy D, Shrestha D, Dhar T (2007) Simultaneous enzyme immunoassay for the screening of aflatoxin B1 and ochratoxin A in chili samples. Anal Chim Acta 584(2): 343-349.

16. Li P, Zhang Q, Zhang W, Zhang J, Chen X, et al. (2009) Development of a class-specific monoclonal antibody-based ELISA for aflatoxins in peanut. Food Chemistry 115(1): 313-317.

17. Tan Y, Chu X, Shen GL, Yu R (2009) A signal-amplified electrochemical immunosensor for aflatoxin B1 determination in rice. Anal Biochem 387(1): 82-86.

18. Rubert J, Soler C, Mañes J (2010) Optimization of matrix solid-phase dispersion method for simultaneous extraction of aflatoxins and OTA in cereals and its application to commercial samples. Talanta 82(2): 567-574.

19. Ibáñez Vea M, Corcuera L, Remiro R, Murillo Arbizu M, González Peñas E, et al. (2011) Validation of a UHPLC-FLD method for the simultaneous quantification of aflatoxins, ochratoxin A and zearalenone in barley. Food Chemistry 127(1): 351-358 
20. Wacoo AP, Wendiro D, Vuzi PC, Hawumba JF (2014) Methods for detection of aflatoxins in agricultural food crops. Journal of Applied Chemistry p. 15.

21. Stoloff L (1979) The three eras of fungal toxin research. Journal of the American Oil Chemists' Society 56(9): 784-788.

22. Khokhar KM (2018) Present status and prospects of chillies in Pakistan. Agri corner.

23. Dailly DAWN (2018) Pakistan's chilli production scorched by water shortages, theft.
24. Fakruddin M, Chowdhury A, Hossain MN, Ahmed MM (2015) Characterization of aflatoxin producing Aspergillus flavus from food and feed samples. Springerplus 4: 159 .

25. FAOSTAT (2013) Agricultural production.

26. Kokkonen M, Jestoi M (2009) A Multi-compound LC-MS/MS method for the screening of mycotoxins in grains. Food Analytical Methods 2(2): 128-140. 